\title{
THE LEGAL TREATMENT OF KNOW-HOW IN BRAZIL: PECULIARITIES AND CONTROVERSIES OF A NEW INTANGIBLE FORM
}

\author{
José Carlos Vaz e Dias ${ }^{1}$ \\ Leonardo Sant'Anna ${ }^{2}$ \\ Bernardo Santos ${ }^{3}$
}

\begin{abstract}
Technical knowledge is one of the most important assets of a company, since it permits competitive detachment from its competitor and quality in production. Therefore, knowledge is relevant to business success. Most of such knowledge are expressed in the form of know-how or technical expertise, not specifically protected as patents or any other form of industrial property rights. This lack of specific legal protection brings inquiries on the nature of know-how and whether it is an adequate legal intangible for exploitation and if it secures enforcement against unauthorized use. This inquire is further heated by the fact that the Brazilian Patent and Trademark Office (BPTO) does not record know-how licensing agreements that stipulate clauses demanding licensee to cease the use of the licensed technology and return it to licensor with termination. Confidential clauses are also not accepted with termination under the arguments of licensee's absorption of the licensed technology. The objective of this article is to address the existing know-how protection under the law of the land and set the possible nature of this legal asset following up the Theory of Property. Recordation proceedings of licensing agreements will also be addressed as an attempt to understand the BPTO's prejudice towards know-how protection.
\end{abstract}

Keywords: Property and Chattels. Industrial Property Rights. Know-How. Trade Secrets. Technology Transfer Agreement. Know-How Licensing.

\section{INTRODUCTION}

It is recognized that more than $70 \%$ of traded technology in the international arena takes place in the form of unpatented technology. ${ }^{4}$ This is relevant since most of the legal and economic discussions on intellectual

\footnotetext{
${ }^{1}$ Adjunct Professor on intellectual property rights at the Faculty of Law of the State University of Rio de Janeiro (UERJ). Legal Director of the Technology Transfer and Innovation Department of UERJ (INOVUERJ).E-mail: jose.dias@vdav.com.br

${ }^{2}$ Adjunct Professor of Commercial Law at the Faculty of Law of the State University of Rio de Janeiro (UERJ). E-mail: 1santanna44@gmail.com

${ }^{3}$ Student of Master in Law from the Faculty of Law of the State University of Rio de Janeiro. E-mail: bernardolbr@gmail.com

${ }^{4}$ According to the data published by the Brazilian Patent and Trademark Office (BPTO), plain know-how or unpatented technology licensing agreement relates to approximately 18\% of the registered agreements during the period of 2000 to 2015. Transfer of knowledge by means of training and technical assistance agreements range from $65 \%$ to $80 \%$ of the registered agreements during the same period of time. Technical assistance is regarded as service rendering of technical nature. Anuário Estatístico de Propriedade Industrial: 2010-2012. Available at http://www.inpi.gov.br/estatisticas/anuario-estatistico-depropriedade-industrial-2000-2012. Access on October 5, 2016.
} 
property are focused on the impact of the patent system and the improvement of its boundaries to secure better rights to the patentee. In addition, this fact is not a surprise, since patented inventions demand the prior fulfillment of the patentability requirements and therefore found in a lessen number. ${ }^{5}$ Further to that, it is difficult to fit the ever-fast high-technology developments into a strict framework of protection, especially in the existing environment of open innovation. ${ }^{6}$

Unpatented technology comes in the form of know-how, which is viewed as any technical knowledge in manufacturing, production and business derived from accumulated experience, skills, ideas, new methods of how to use and develop a knowledge, and transmitted through personal services and the disposal of drawings, specifications, formulae, blueprints and other means.

Due to the impact in production and business, know-how is an asset that brings advantages to those who develop or legitimately possess and exploit technology. Know-how is also an adequate subject matter for international commercial agreements that grant specific third parties - so-called licensees - the right to exploit the technical knowledge and permit the owner to obtain remuneration from the technology exploitation.

Notwithstanding the value of know-how, controversies arise on its legal nature that flows to inquiries on whether it should be considered as a property under the Theory of Property and the concept provided by article 1,228 of the Brazilian Civil Code. ${ }^{7}$ There are also doubts about know-how as an effective industrial property right, not enlisted as such by the law of the land, ${ }^{8}$ and how its protection takes place. The basic question in this regard

Know-how licensing on the other hand may be framed as a plain licensing where the owner enters into a separate license agreement to exploit the unpatented technology or as a bundle or hybrid licensing where know-how is embedded into a broad arrangement or technology package comprising the use of different intellectual property rights or intangibles. Boletim Mensal de Propriedade Industrial: Estatísticas Preliminares. Ano I, n. 3, March 2016. Available at http://webcache.googleusercontent.com/search?q=cache:TJlrBeJ0-

g0J:www.inpi.gov.br/estatisticas/arquivos/publicacoes/boletim_mar-2016.pdf $\&$ \&cd=13\&hl=en\&ct=clnk\&gl=br. Access on October 5, 2016.

Following up the comments of Karl Jorda, a 2003 survey promoted by the Intellectual Property Owners Association (IPO) evidenced that $88 \%$ of respondent executives viewed proprietary technology (not patent) as a key source of competitive advantage. JORDA, Karl. IP Handbook of Best Practices. Chapter 11.5. Available at http://www.iphandbook.org/handbook/ch11/p05. Access on October 14, 2016.

${ }^{5}$ See TEE, David. “The Market for Know-How and the Efficient International Transfer of Technology". Research Paper 608. Graduate School of Business, Stanford University, June 1981, p.1-35. It has been noticed in a paper written by Branstetter et al that strong IP rights in a technology recipient country does not necessarily enhance deeper technology transfer. Fostering technology transfer comes from the involved costs transactions related to enforcement and the adequate relationship between the provider/licensor and the recipient/licensee party, including proper means of technological absorption and royalty payment. BRANSTETTER, Lee G. et al. "Do stronger Intellectual Property Rights Increase International Technology transfer? Empirical Evidence from U.S. Firm Level Panel Data”. The Quarterly Journal of Economics, February 2006, p. 321-349. Available at http://repository.cmu.edu/cgi/viewcontent.cgi?article=1042\& context=sds. Access on September 10, 2016.

${ }^{6}$ There exists in Brazil the Innovation Law (Law n. 10.973 of December 2, 2004) that promotes partnerships between public research centers and universities and companies for the investment and research and development programs. See http://www.planalto.gov.br/ccivil_03/_ato2004-2006/2004/lei/110.973.htm. Access on September 29, 2016.

${ }^{7}$ Law 10,406 of September 4, 2002. Available at http://www.planalto.gov.br/ccivil_03/leis/2002/L10406.htm. Access on October 15, 2016.

${ }^{8}$ Law 9,279 of May 14, 1996, article 5. Available at http://www.planalto.gov.br/ccivil_03/Leis/L9279.htm. Access on October, 15, 2016. 
would be: is know-how viewed as a matter for business transaction where the owner would enforce its rights essentially through an agreement?

Scholars view know-how as a "property value", 9 but not adequately as a "property right" due to the lack of express recognition as such by the law and the difficulties to frame this intangible under the rules of the Theory of Property. The lack of specific recognition as a property right under Brazilian law and the attempt to rule it by other legal mechanisms - general-tort-law of the Civil Code and unfair competition - lead to the understanding that know-how merits only tangential protection.

The existing questions on the legal nature of know-how has significant practical impacts, mostly related to the effectiveness, such as the available remedies against misappropriation or misuse. The boundaries of a knowhow licensing are also a matter of usual discussion due to the restrictive attitude of the BPTO that does accept recordation of know-how licensing that hampers licensee from using the disposed know-how after termination of the agreement. The agency does not permit further the recordation of clauses that establish the requirement of licensee to return the transmitted technology to the owner/licensor. The argument is that know-how is a not a property right and once taught or delivered, the return of the technology would impose unreasonable burden to licensee.

This peculiar treatment of know-how licensing in Brazil has called the attention of foreign technology owners who frequently inquire on whether a judicial remedy could be actionable or a feasible in case a licensee refuses to cease the use of the know-how after contractual termination.

This article will tackle the relevant aspects related to the nature of know-how under discussion in Brazil and the existing legal framework, including the specification of the essential elements. The basic task is to depict the manner know-how is viewed and protected under the local laws. By determining the protection, it will be possible to venture into the practical side and attempt to address existing challenges by legal scholars grounded on the restrictions to license a know-how to third parties and securing the full property of the technology after the contractual termination.

This article starts by tracing the concept of know-how and depicting its elements and characteristics under the beliefs that it fits under categories of property rights. It will further develop to existing discussions on whether know-how is indeed a confidential information or undisclosed technology thereby expressed only in a confidential manner. Is confidentiality an essential requirement for know-how existence and protection?

Central to the proposed objective is the description of the legal requirements for a legal asset (so-called "bem jurídico") to be classified as a property right. Since most of the property requirements were tailored during

\footnotetext{
${ }^{9}$ GREENBERG, Suzanne F. "The WIPO Model Laws for the Protection of Unpatented Know-How: A Comparative Analysis". Berkeley Journal of International Law, Berkeley, v. 3, 1985, p. 63-65. Available at http://scholarship.law.berkeley.edu/bjil/vol3/iss1/3. Access on October 1, 2016.
} 
the Roman times, it is a needed challenge to address know-how under the strict property perspective set out by Civil Code. Next, we will move to discussing the general transformation of property and the flexibility of the legal requirements to welcome protection to know-how, trade secrets, business goodwill, trademarks and other valuable intangible assets to our society.

The third task is to examine know-how under the existing restrictions for recordation of licensing and technology transfer agreements. The analysis of the recordation of know-how agreement will be crucial for the reader to understand in real terms the problems caused by the dephysicalization of property and the relevance of know-how, and the problems that foreign licensors may face when licensing unpatented technology in Brazil.

In view of the proposed objectives, this paper needs to be viewed as an opportunity to promote discussions on the unreasonable limitations imposed to know-how in Brazil and to foster further research on a matter not commonly addressed despite having a strong impact on the exploitation of an intangible and technology transfer in Brazil.

\section{UNDERSTANDING THE CONCEPT OF KNOW-HOW: NOT SECRET AND TRADE SECRET}

At assessing the applicable literature, know-how is an expression that holds similar meaning in different fields of science and technology relating essentially to the ability, expertise and skill of someone to perform efficiently a specific task. ${ }^{10}$ Therefore, it broadly encompasses patented and unpatented technical knowledge, professional specific abilities, ideas, methods, formulas, software, product testing, quality control techniques, and any kind of technology applied by someone to reach a desirable end.

When examined under a legal viewpoint, know-how may hold however a more restrictive understanding in the sense that it designates a body of information comprised of unpatented inventions held by one or a limited number of owners to solve technical problems and secure competitive advantage to companies. This concept may be taken into consideration to depict the elements of know-how and to set the expected requirements for legal

\footnotetext{
${ }^{10}$ According to the Merriam-Webster Learner Dictionary.com, know-how holds the meaning of "knowledge of how to do something smoothly and efficiently: Available at http://webcache.googleusercontent.com/search?q=cache:dyDpl6awmhsJ:www.merriam-

webster.com/dictionary/know\%25E2\%2580\%2593how $\& \mathrm{~cd}=4 \& \mathrm{hl}=\mathrm{en} \& \mathrm{ct}=\mathrm{clnk} \& \mathrm{gl}=\mathrm{br}$. Access on October 10, 2016. At the same pace, the business dictionary organized by WebFinance, Inc. holds a similar but an extensive meaning, as follows: "Expert skill, information, or body of knowledge that (1) imparts an ability to cause a desired result, (2) is not readily available, and is (3) outside the public domain. Know how may include tangible material (such as blueprints, formulas, instructions, patterns, specifications, and trade-secrets) or intangibles (such as manufacturing practices, marketing concepts, quality control, and testing techniques) which are not common knowledge. In technology transfer agreements, know how is the most valuable factor and may have an indefinite enforceable life. In legal terms, it may be defined as "any industrial information and technique likely to assist in the manufacture or processing of goods or materials." Available at http://webcache.googleusercontent.com/search?q=cache:P9qXaRN95wYJ:www.businessdictionary.com/definition/know-
} how.htm. Access on October 10, 2016. 
protection.

It is accepted that know-how is linked to technology not protected by industrial property rights, such as patents and utility models. This detachment from unpatented technology occurred mainly as from the 1970's when know-how licensing was affirmed as a relevant category of agreement comprising essentially complementary techniques to patent licensing. ${ }^{11}$ This means that a licensee may be granted with the rights to exploit a patented invention, but additional knowledge is required to make it work correctly.

Since then it has conquered a separate value from patent and has been receiving specific valuation and legal treatment, including the identification of validity requirements. Moreover, know-how has shown autonomous existence, independently of a prior patent invention or utility model existence.

Therefore, the first characteristic of know-how is the intangibility nature, which is expressed by the supply of data or instructions but lacks adequate framing as patent rights. ${ }^{12}$ Since know-how is conceived as relating essentially to unpatented technology, ${ }^{13}$ it has approximated largely to trade secret and thereby trade secret has been classified as a type of know-how. ${ }^{14}$

Although know-how and trade secrets arise from the same tree trunk, it is recognized that know-how has a broader content, since it may comprise confidential or non-confidential information. Trade secrets hold further a distinguishing element, which is the secrecy feature in an objective sense. This characteristic determines the requirement of the holder to evidence an active and reasonable conduct to keep knowledge undisclosed to unauthorized third parties. In this matter, another difference arises: while the purpose of know-how is to permit the use and exploitation of the technology or the undertaking of a specific task efficiently, trade secret seeks to maintain the information out of reach of unauthorized parties and undesirable competitors. ${ }^{15}$

Such feature involves necessarily the adoption of non-disclosure agreements and security policies, imposition of fines to those who breach the confidentiality and other precautionary measures to establish

\footnotetext{
${ }^{11}$ During the 70 's and 80 's, attorneys and law scholars consistently addressed technology transfer agreements as they were regarded as effective instruments to promote the disposal of technology to developing countries. According to WIPO's Model of Technology Transfer, patent licensing, trademark licensing, know-how licensing, turn-key and consultancy and technical assistance were ranked at that time as the most relevant agreements for the technological connection between the North and South. See WIPO Model Law for Developing Countries on Invention, v. II, 1980 . Available at ftp://ftp.wipo.int/pub/library/ebooks/ModelLaws/841e_vol_2.pdf. Access on October 15, 2016. See also GREENBERG, op. cit.

${ }^{12}$ Know-how differs from patented invention in the sense that patents demand the compliance of the patentability requirements (article 10 of the Brazilian Industrial Property Law), besides not falling within one of the technologies not classified as invention (article 8) and one of the prohibited events due to infringement of the public order norms and to ethics and moral (article 18).

${ }^{13}$ Non-patented means technology that could be patentable but the inventor/owner decides not to patent it. Non-patentable means that the patentability requirements are not met to deserve protection, such as a software or other technology not framed as invention, following the rules of articles 8, 10 and 18 of the Industrial Property Law.

${ }^{14}$ DOMINGUES, Douglas Gabriel. "Segredo Industrial, Segredo de Empresa, Trade Secret e Know-how e os Problemas de Segurança das Empresas Contemporâneas.” Revista Forense, Rio de Janeiro, v. 85, n. 308, p. 27-33.
} 
psychological ${ }^{16}$ and material barrier to access the restricted technology. ${ }^{17}$

According to Brazilian scholars, the secrecy nature creates two essential requirements to deserve legal consideration for protection. The first one is to ensure that the knowledge is secret or not known or published. Information in the public domain and that is already incorporated into the state of art cannot be secret. The second would be the actual steps to maintain the secrecy in force. As pointed out by FISCHER ${ }^{18}$, "a document which is kept in a simple file and is commonly left unattended on top of an office desk is not eligible for trade secret protection (TRT, 1a. Região - Ac. 3a. T. 550/70)."

The secrecy requirement does not apply to "not secret know-how" and therefore the lack of absolute secrecy does not jeopardize the know-how nature nor its value in commerce. However, scholars hold an equal understanding that a certain degree of confidentiality and the adoption of measures to restrict access by third parties is expected in "not secret know-how".

It is recognized that there seems to be an interrelation between the access restriction and the higher value of know-how. This means that the higher the secrecy or the difficulty to access the unpatented technology, the more value it holds to third parties. This is the case of a list of clients or suppliers. The enlisted clients are knowledgeable to employees and few competitors, but they are not extensively or easily available to third parties or looked upon as public domain information. In this matter, LEONARDOS explains the following: ${ }^{19}$

"In relation to know-how, this can be a technique or procedure protected by secrecy, but it may be a technique or procedure dominated by different companies, permitting an interested party to learn and therefore contract with any of the companies. This means that know-how agreements can take place where the matter of the contract may be either protected by secrecy or not, which evidences that know-how and trade secret cannot get mixed up.

The fact that know-how can be available from diverse sources does not withdraw its economic value, since there are no alternatives to those who do not hold it but obtain it unless it decides to develop it (that can be expensive and time consuming) or contact with one of the sources to learn from it. It is clear that secret will have normally a higher value than know-how not protected by secret, since the existence of only one source will make the price of the technique or procedure higher than in case of alternative sources." [free translation]

\footnotetext{
${ }^{15}$ The Brazilian attorney Elizabeh Kaznar Fekete has devoted in her book a great deal of discussion about the differences between know-how and trade secret. FEKETE, Elizabeth Kaznar. O Regime Jurídico do Segredo de Indústria e Comércio no Direito Brasileiro. Rio de Janeiro: Forense, 2003, p. 46-60.

${ }^{16}$ Psychological barriers relate to an employment position where only high ranked employees in a company will have access to the involved competitive technology. Usually, non-compete clause and non-disclosure agreements are demanded as prior requirement to access the secret. See DIAS, José Carlos Vaz; COSTA, João Marcelo Sant'Anna. "Migration of Brazilian intellectual workers in the international market: identification of enticing employees acts and the legal mechanisms to cease the appropriation of technology and unfair competition practices," Revista de Direito Internacional, Rio de Janeiro, v. 13, n. 1, 2016, p. 285-307. See also DESSEMONTET, François. "Protection of Trade Secrets and Confidential Information.", p. 14-19. Available at https://www.unil.ch/cedidac/files/live/sites/cedidac/files/Articles/Protection\%20Trade\%20Secrets.pdf. Access on October 15, 2016.

${ }^{17}$ Material barriers are as tangible obstacles between the secret information and those not authorized to access it. I.e. placing the secret information in a safe box or in a room that only authorized persons may enter.

${ }^{18}$ FISCHER, Georges Charles. "Trade Secrets Protection in Brazil”. Les Nouvelles, Washington, Dec. 1987, p. 69.

${ }^{19}$ LEONARDOS, Gabriel. Tributação da Transferência de Tecnologia. Rio de Janeiro: Forense, 1997, p. 78.
} vol.09, nº. 04, Rio de Janeiro, 2016. pp. 2312-2334 
Following up the secrecy matter, it is expected that know-how possesses a certain degree of novelty or "intellectual contribution" of something developed and not known in the market (third element). ${ }^{20}$ The novelty does not have to be however absolute, but instead linked to the "non-availability to the public" principle combined with the technical development and the degree of technical importance to a specific industrial/business sector or that provides competitive advantage not commonly or easily available in the market. ${ }^{21}$

The need of know-how to apply to the industrial and business fields is understood to be the fourth characteristic of this intangible asset, including any knowledge related production and service rendering in any field of business activity. This element would exclude technical information essentially for private use not commercially applicable. It would include those of professional knowledge or nature embedded into a service rendered with commercial effects, such as that related to a physician or architect services. ${ }^{22}$

The value of know-how is the fifth and crucial element of existence and validity. Notwithstanding the non-secret nature, experts have taken into consideration the competitive edge of know-how to companies, the impact on inventory valuation and the contribution to capital, and the expected revenues that owner may obtain from licensing agreements. ${ }^{23}$ It is required that one demonstrate the relevance of know-how to business activities, otherwise it cannot be regarded as a subject matter for legal protection.

The specific inquire in this regard would be assessing if know-how is a chattels capable to secure to its owner the possibility to exercise rights on the property. This matter will be addressed in the next chapter where the formation of property rights and the involved attributes will be addressed to assert the property nature of knowhow.

\section{THE PROPERTY NATURE OF KNOW-HOW: HOW MUCH PROPRIETARY AND HOW MUCH A CONTRACTUAL RIGHT?}

It is undeniable that know-how holds a "property value" due to its importance to modern society. A

\footnotetext{
${ }^{20}$ According to Braga, "Novelty, in this particular, I understand that the degree of novelty does not get confused with the originality demanded for patentable innovations. It has been said that businessmen may opt by the secret instead of patent, since it does not aim to revel all creation process in the patent application. Besides, to the effects of trade secret, novelty may assume different aspects. Usually, the employed technology is known - not needed to say on patentable innovation - but the company may develop mechanisms that simplify the production of the product with the lowering price to consumer. The great appeal consists in the price of the product that will foster the sale, which is the reason that we insist that novelty in the sector of knowledge is not equal to novelty demanded - from inventors for granting a patent." BRAGA, Rodrigo Bernardes. "O Segredo de Negócio no Direito Brasileiro: Trade Secret in the Brazilian Law". Revista Forense, Rio de Janeiro, v. 401, p. 15.

${ }^{21}$ According to revoked Peruvian Supreme Decree No. 007-71-1C (1971), a set of rules were set to protect know-how and established the requirements for legal protection. Article 88 of this revoked law set novelty as a legal requirement for protection. GREENBERG, Suzanne, op. cit, p. 62-63. See also CORREA, Carlos M. "Legal Nature and Contractual Conditions in Know-How Transactions". Available at http://digitalcommons.law.uga.edu/cgi/viewcontent.cgi?article=1958\&context=giicl. Access on October 15, 2016

${ }^{22}$ CORREA, Carlos M., op. cit, p. 463-464.
} 
unique method of production may bring competitive edge to a businessperson in commerce or increase productivity in the industry. This leads to the reasonable understanding that this type of unpatented technology should be an adequate subject matter of property rights, meaning that such intangibles are valuable assets and deserve protection against misappropriation or usurpation, notwithstanding the lack of a specific law provision defining it as property. ${ }^{24}$

Although know-how is looked upon as a peculiar category of intangibles or technical knowledge, its nature needs to be opposed to the Theory of Property set out at the Civil Code and prevailing doctrine written by legal scholars on the matter. By looking closely at this Theory, one can examine the obstacles that know-how may face to be framed as a proper "legal asset ("bens jurídicos") with relevance to the existing intellectual property framework.

The civil law is looked upon as a system whose origin comes from the codification of the Corpus Juris Civilis of Justinian ${ }^{25}$ in the Roman Empire blended with rigid dogmas provided for by the influence of the scholasticism of Glossators and the Commentator and the development of Catholicism in Europe. Its main characteristic is the prevailing highly and formal structured codes and laws, often stating idealistic rules and addressing phenomena and legal assets into categories rather than extracting knowledge and rules from the rendering of court decisions, as it happens in the common law system. ${ }^{26}$

Since Brazil is a civil law country, the legal culture holds deep roots in the development of the Roman law due to the influence of European codes, especially the French Civil Code of 1804. Most recently, the Roman heritage is expressed in the existing Brazilian Civil Code, ${ }^{27}$ which suffered influence from the German Bürgerliches

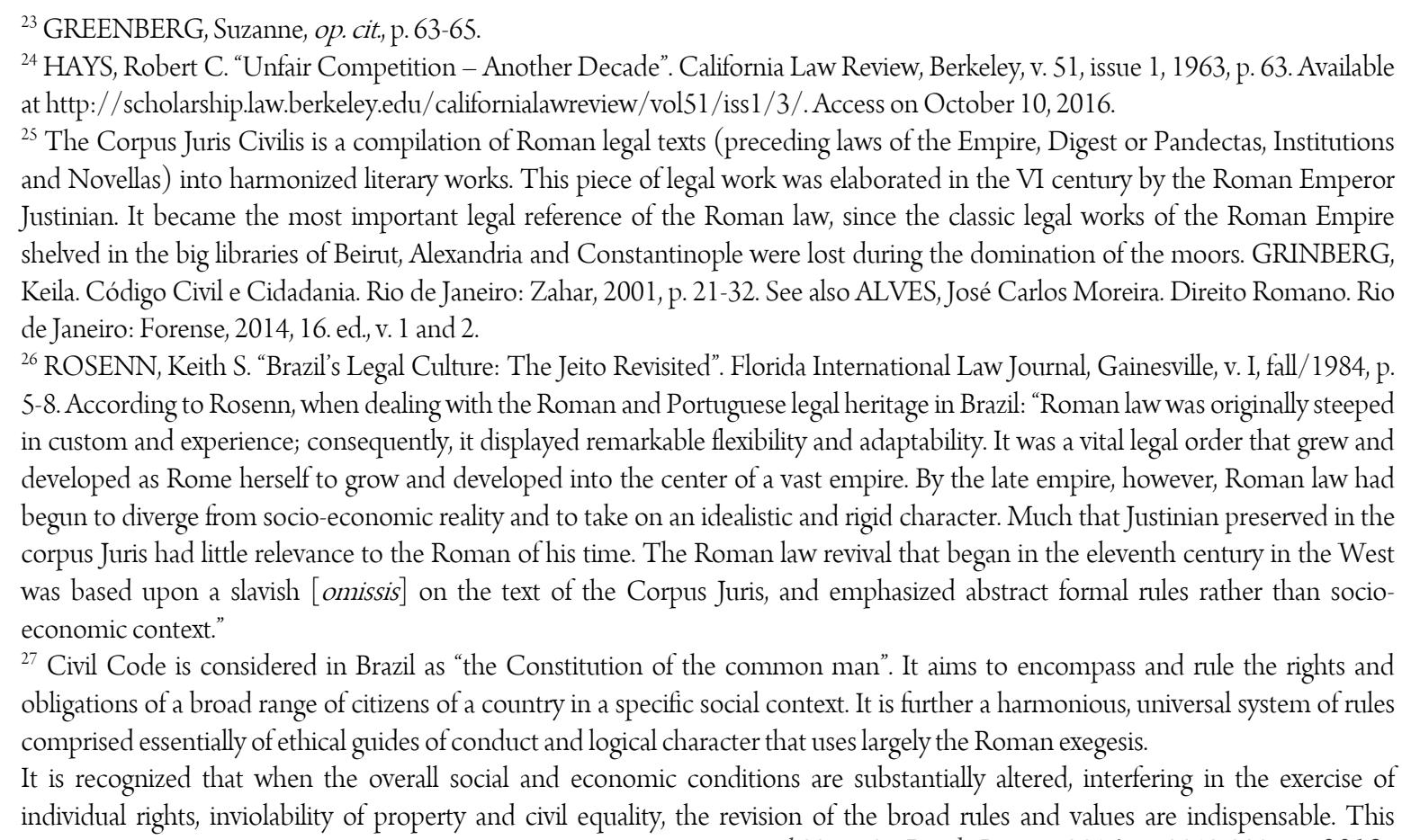
vol.09, no. 04, Rio de Janeiro, 2016. pp. 2312-2334 2319 
Gesetzbuch of 1900 and from the Codice Civile Italiano of 1942. Further to that, a large amount of provisions from the revoked Brazilian Civil Code of $1916^{28}$ was incorporated into the existing Civil Code.

As a result, Brazilian scholars and attorneys are trained at the faculty of laws to place each phenomena and "legal asset" into categories, and assess their legal requirements. The assessment exercise aims to assert the phenomena into one of the possible protection by the legal system: property rights, contractual rights or personality rights. This is clearly seen when private property rights are under discussion. Contrary to contract law where any business transaction may be framed as contractual relationship, not every legal asset can be a property matter. ${ }^{29}$

According to the law of the land and the studies of scholars (doctrinal development) ${ }^{30}$ on the Theory of Property, there are prior requirements yet to be fulfilled for a "legal asset" to be classified as a real right or property right. Before the requirements are specified, one should understand that property rights deal essentially with the power of a legal owner on a thing or "legal asset". Therefore, owner of "legal matter" holds all available remedies disposed at the Civil Procedural Code and specific applicable laws, such as ex parte preliminary injunctions, temporary restraining orders, search and seizure and indemnification court measures.

The first requirement comes from the understanding that real rights are established by a numerus clausus list in the sense that the extension of matters or "legal assets" may be subject to property ${ }^{31}$ only if they are established as such by law. Although the doctrinal development reserves to the legislators the right to create Real Rights ("Direitos Reais") 32 authors have understood the numerus clausus concept also apply to defining the "legal

philosophical concept was largely used by the notorious Instituto dos Advogados Brasileiros (Brazilian Institute of Attorneys) since the middle of the XIX century to support the revocation of the Ordenações Filipinas, which was promulgated in Portugal in 1603 (applicability extend to its colonies) and it was inadequate to the Brazilian reality. Furthermore, a new social and economic reality was the driving force for the adoption of the Civil Code of 1916, including the abolition of slavery and the industrialization of Brazil. For a further reference, Ordenações Filipinas was a compilation of Roman law, customary usage, main rules of the Visigothic Code, the Siete Partidas, Canon law and the general legislation of Portugal since 1211. According to ROSENN, Keith S., op. cit., p. 12: "Much of its [Ordenações Filipinas] draftsmanship was unclear to begin with, and it became such a hodgepodge of overlapping and inconsistent amendments that a divining rod seemed as sure to guide to legal research as any other method. Nevertheless, the Ordenações remained the bulwark of Brazil's civil law until 1917, almost a century after independence and a full fifty years after Portugal had relegated the Ordenações to the statutory scrapheap."

28 Also known as Law 3,071 of January 1, 1916 (revoked by Law 10,406 of January 10, 2002). Available at www.planalto.gov.br/ccivil_03/leis/L3071.htm. Access on October 10, 2016.

${ }^{29}$ Legal assets require to be framed in one of the classes of property provided for at Book II (Chapter I to III), such as movable of immovable property, fungible and consumable property, divisible or indivisible property, singular or collective, main or ancillary (improvements) and public property. Following up each category, the legal asset will need to fulfill the specific requirement and will receive peculiar treatment.

${ }^{30}$ Legal scholars in Brazil are viewed as experts that attempt to adjust the principles of laws to the complexities of business transactions and promote legal understanding and exegesis based on the socio-economic context.

${ }^{31}$ Property is enlisted as a Real Right together with pledge, mortgage, servitudes and others, in accordance with article 1,225 of the Civil Code.

${ }^{32}$ Real rights refer to a typified relationship between the owner and the owned thing, such as property or a pledge. 
assets" that may be subject to property. ${ }^{33}$ The general knowledge is that the numerus clausus system requires the examination of the exhaustive list of property set by out by law so as to identify the assets that may be encompassed by property. In this sense, one has to look into Book I of the Civil Code (articles 79 to 103), which provides the categories of "legal assets" that may be framed as or subject to property rights. For example, immovable or movable, things that exist by themselves or improvements, divisible and indivisible, are matters subject to property protection.

Patents and trademarks are classified as chattels or moveable property in accordance with article 5 of the Industrial Property Law, thereby fulfilling the affirmed numerus clausus requirement, as follows:

"Art. 5. For legal effects, industrial property rights are deemed to be movable property." [free translation, highlight added]

The numerus clausus requirement may be clearly explained in the words of our scholars Cristiano Chaves de Farias and Nelson Rosenwald in the following manner: ${ }^{34}$

"Destined to be enforceable against collectivity, not all property rights may be legally recognized if there are no previous norms establishing them. Therefore, inserted into the public order regime, the real rights [rights subject to property] are numerus clausus, exhaustively enlisted, specified in the detailed list of article 1,225 of the Civil Code. ( ...)

The numerus clausus formulae was elaborated in principle, as a manner to preserve the absolute rights of property. Fearful of any restrictions that the State could impose on property rights, the legislators of the XIX century defined a list of real rights complementary to property. As a result, the proprietor could have a legal assurance that its rights on a matter would be kept untouched and that the only restrictions to the rights would be the enlisted events in the law and always resulting from an act emanated from its autonomy. ( ... )" [free translation]

As one may see, the numerus clausus system does not extend to fixing which legal matters would fall into the property category, but this understanding is frequently called on legal debates on the legal nature of knowhow. $^{35}$

Added to the numerus clausus requirement, only "legal assets" are subject to property rights. "Legal assets" are understood as any kind of asset (material or immaterial) that is financially measurable and that may be subject to a legal relationship or generate business transactions. This statement makes sense in view of the fact that the law concerns on protecting matters that are valuable to society or to the collectivity, such as cars, immovables, company assets, business goodwill, among other relevant matters.

\footnotetext{
${ }^{33}$ CORREA, José Antonio B. L. Faria "Considerações Sobre o Tratamento do Segredo de Negócio: os efeitos da nova lei de propriedade industrial.” Revista da ABPI, Rio de Janeiro / São Paulo, n. 27. March/April, 1997, p. 30-38.

${ }^{34}$ During Roman times, there existed a small list of things that would be framed as property and generate dominion rights to the owner over the thing. FARIAS, Cristiano Chaves de F.; ROSENWALD, Nelson. Direitos Reais. 3. ed. Rio de Janeiro: Lumen Juris, 2006, p. 1-11. The numerus clausus requirement may be further explored in TEPEDINO, Gustavo; BARBOZA, Heloisa Helena; MORAES, Maria Celina Bodin. Código Civil Interpretado, Conforme a Constituição da República. Rio de Janeiro: Renovar, 2014, vol. III. 2. ed., p. 497-498 and in ASCENSÃO, José de Oliveira. Direito Civil Reais. Coimbra: Coimbra Editora Limitada, $1983,4$. ed., p. 145-160.

35 FIGUEIREDO, Paulo. "Problemas do Licenciamento de Tecnologia Não Patenteada". Available at http://www.tjr.jus.br/documents/10136/1186838/prob-licenc-tec-n-patent.pdf. Access on October 20, 2016.
} 
Therefore, adding or eliminating "legal assets" from the legal system matches to the existing social and economic development of mankind in a specific time, territory and political/economic condition.

This understanding further asserts that property is a legal fiction created to secure ownership, appropriation of things and assets for the purpose of the owner's exploitation. Therefore, adding or eliminating "legal assets" from property comes at the convenience of the legislator following the needs of society. This asserts the common knowledge that intellectual property rights are effective property matters. ${ }^{36}$

The third recognized requirement for a "legal asset" to be regarded as property is the confirmation that the asset may be adequately matter for acquisition, which encompasses the possibility to be exercised by its owner and through authorized third parties. For example, the sun or the sky cannot be matters of property due to the impossibility of appropriation and ownership. On the other hand, a screwdriver, a plant variety and a trademark would be adequately regarded as property, as the owner and third parties can easily manipulate it.

This requirement is resolved by framing the "legal asset" in one of the classes of property set out by articles 79 to 103 of the Civil Code. Matters concerning intellectual property rights are framed in article 82 and 83 of the Code as adequate matters when viewed together with the concerned law, as follows:

Civil Code

"Art. 82. Things that are capable of movement by themselves or that can be removed by extrinsic force, without altering their substance or their socio-economic purpose, are moveable property.

Art. 83. The following are considered to be moveable property for all legal effects:

I. energy that has economic value;

II. real things in movable objects and actions on such real rights;

III. personal right that are patrimonial in character and action on such rights." [free translation, highlight added]

Copyright Law

"Art. 3. Copyright shall be considered movable property for the purposes of this Law." ${ }^{37}$ [highlight added]

Industrial Property Law

"Art. 5. For legal effects, industrial property rights are deemed to be movable property." [highlight added]

\footnotetext{
${ }^{36}$ During the Roman times, individuals could be classified as things and then be subject to property, especially when they came from invasion and territory domination, so-called slaves or foreigners. Slaves were also matters of property in Brazil during colonial times. This expresses the idea that the concept of property under the Roman Legal System was not linear, but mixed with political and social needs and interests. According to the Brazilian scholar Caio da Silva Pereira: "Only the Roman citizens could be owners, only the roman soil could be their property, since the domination nationalized the conquered land. The acquisition technique mancipatio - that was a typical Roman ceremony restricted the phenomenon and limited the dominium ex iure quiritium. At a later stage, it was extended the ius commercii to foreigners (right to appropriate things for commercial purposes), it was amplified the phenomenon and limited the dominium ex iure quiritium." [free translation]. PEREIRA, Caio Mário da Silva. Instituições de Direito Civil. Rio de Janeiro: Forense, 2004, 8. ed. v. 4., p. 82. See also the discussions related to the adequate framing of patents, trademarks and other intellectual intangibles as property rights in DIAS, José Carlos Vaz e. "Business Transaction of Intellectual Intangibles: The Evidence and the Peculiarities of a New Form of Property Rights”. Revista Quaestio Iuris, Rio de Janeiro, v. 8, n. 3, 2015.
}

${ }^{37}$ Law 9,610 of February 19, 1998. Available at http://www.wipo.int/wipolex/en/details.jsp?id=514. Access on October 18, 2016. vol.09, no. 04, Rio de Janeiro, 2016.pp. 2312-2334 2322 
It is important to note that Brazil requires a trademark to be registered and a patent to be granted at the BPTO to secure the exclusive rights to their titleholders or for third parties to exploit commercially the registered trademark/granted patent and enforce rights related thereto in court, as provided by articles 42, 129 and 130 of the Industrial Property Law. Such requirement is justified by the fact that registered trademark/granted patent are seen under the law as rights recognized by a competent state agency, therefore granted, and secured by it.

Further to that, the concerned "legal asset" needs to permit owner to extensively exercise the property (and obtain profit from it) by means of the legal powers or "attributes" set out by article 1,228 of the Civil Code. It needs to permit the direct exploitation of the asset (ius utendi), the right to receive the fruits from third parties' exploitation (ius fruendi), and the assignment or sale of the asset to someone else (ius abutendi). ${ }^{38}$

The exercise of property secures further the recovery of the protected asset from unauthorized use by third parties (rei vindicatio) and the compensation for losses and damages, simply by evidencing the ownership of the asset. ${ }^{39}$ This is an evidence of the known erga omnes effect of property that binds tightly the "legal matter"/thing to the owner and opposes absolutely against third parties.

Added to the aforementioned attributes or owner's powers is the need of any property to fulfill the social function. This element demands the owner to exercise the property according to the economic and social objectives related to the nature of the matter or intangible and the characteristics of the granted rights. ${ }^{40}$ For example, a trademark is an adequate intangible for property right insofar as the titleholder extensively exploit it in the market, distinguish goods and services and fulfill the market needs, including the exploitation of it as a transaction.

At examining the elements of know-how, it is possible to state that the difficulty to view it as a proper matter of property rights comes essentially from the lack of specific laws enlisting it as chattels or moveable. This

\footnotetext{
${ }^{38}$ Article 1,228 of the Brazilian Civil Code stipulates that: "The proprietor has the power to use, exploit and dispose of the thing, and the right to recover it from the power of anyone who wrongfully possesses or hold it."

Legal attributes of property under the law of the land are those legal powers that assure proprietors deal directly and immediately related to the protected object and intangible. This means that the titleholder or proprietor may use and dispose the concerned objects and intangibles by any means insofar it does not violate third parties and complies with the Social Functionality. PEREIRA, Caio Mário da Silva, op. cit,. p. 159-172.

${ }^{39}$ The rei vindicatio comes under the industrial property rights at a great extent from the exclusive rights (right to exclude others) granted by the Industrial Property Law, in particular articles 42 and 129 of the aforementioned law. Law 9,279 of May 14, 1996, articles 42 and 129. Available at http://www.wipo.int/wipolex/en/text.jsp?file_id=125397. Access on October 20, 2016.

${ }^{40}$ The social function of property rights is broadly outlined in the first paragraph of article 1,228 of the Civil Code: "The right of ownership must be exercised in a manner consistent with its economic and social ends that, in conformity with the provisions of special legislation, so as to preserve the flora, fauna, natural beauty, ecological equilibrium and artistic and historical patrimony, avoiding pollution of the air and water."

The Industrial Property Law sets out forfeiture as an event for trademarks rights end and an effective instrument due to noncompliance of the social functionality principle. Forfeiture takes place due to the non-use of a registered trademark for a period of five (5) years as from the grant or if the registered trademark has been used in a modified form that implies modification in its original characteristic as granted by the BPTO. See Law 9,279 of 14 May 1996, articles 143-145. Forfeiture is available to patented inventions, but not a mechanism available to copyrighted works.
} 
means that the numerus clausus requirement seems not to be adequately fulfilled by the know-how concept. ${ }^{41}$

Before addressing this difficulty, it is appropriate to state that know-how has a similar intangible nature to a patented invention by which the owner can exploit directly the essence of the technology in the production line and add competitiveness to a business. Although the rights under it are not limited in time, like a patented invention, the lack of a prior registration or state recognition does not interfere in its existence or with the possibility of preventing misappropriation, nor in the owner's exploitation. The lack of prior recognition (by means of registration, for example) makes in fact know-how more "volatile" to disclosure and public domain, thereby making the restriction to access provision or the confidentiality clause important. Moreover, know-how does not suffer the territorial and time-frame limit imposed to patented inventions, which makes know-how in a sense to match better the legal development of property on things. Last but not the least, no technology lives forever, as it is recognized that knowledge is fast moving and linked to human creativity thereby making technologies outdated in time and according to the needs of mankind and companies.

Know-how is also an eligible matter for exploitation in the sense that it may be used directly in production by the owner and used by others without the deterioration of the novelty and the level of demanded secrecy. It is worth mentioning that know-how is usually disposed to others by means of specific agreements whether a Know-How License or a confidentiality agreement in case of secret know-how - where stringent clauses are stipulated to deal with confidentiality procedures of the transmitted information and the return of it to the owner/licensor after contractual termination.

There is also no obstacle to use know-how as collateral or security interest, since such intangibles are valuable assets to a company's existence and competitiveness, like a patented invention or a software. Articles 1,410 to 1,472 of the Brazilian Civil Code deal with security interest as collateral for guarantees, as it determines that moveable things and rights may be offered and disposed to secure payment or performance of a contractual obligation. Therefore, trademarks, patents, industrial design, know-how, business goodwill and other intangibles may be collateral for a debt, as they are either rights or recognized movable. ${ }^{42}$ Each intangible has a peculiarity as a collateral. Trademarks and patents require prior registration of the lien at the BPTO. Copyrights do not require prior registration at any government agency. In fact, the basic requirements of the lien as extracted from the Civil Code for moveable are that ${ }^{43}$ : (i) the moveable become subject to property in existence and by law; (ii) the

\footnotetext{
${ }^{41}$ According to IP attorneys, the First-to-File System of the industrial property rights raises questions about the protection of unpatented technology due to the lack of prior filing or registration procedure. Further to that, article 2 of the Industrial Property Right does not enlist know-how as an industrial protection matter. FIGUEIREDO, op.cit.

${ }^{42}$ Moveable should include physical things that can move from one place to the other and immaterial rights. The Civil Code has eliminated the requirement of effective conveyance and possession of the collateral by the debtor. Accordingly, the effective conveyance of the chattel is dispensable and the "fictitious" transfer may take place by means of an agreement that secures the lien. Therefore, know-how and other intellectual property rights may be framed as collateral.

${ }^{43}$ DIAS, José Carlos Vaz; PITANGA, Daniel. "Brazil". In: "Trademarks in 42 jurisdictions worldwide”. Getting the Deal Through, vol.09, no. 04, Rio de Janeiro, 2016. pp. 2312-2334 2324
} 
moveable be capable of conveyance to the creditor's possession following the peculiarities of the "legal asset" and

(iii) there be a main agreement creating the credit. ${ }^{44}$

To perfect and enforce the security interest agreement bearing know-how as collateral, the agreement should be recorded at the Registry of Titles and Deeds or other identified agency, specifically provided by law. The justification for the registration of the agreement is to place any interested party or businessmen on constructive notice that the pledge of the know-how may prevent an assignment to or a guarantee to third parties. ${ }^{45}$

The ability to explore directly and indirectly the intangible asset by its owner or by third parties further expresses the power of the owner to recover the intangible against misuse or misappropriation of unauthorized third parties (rei vindicatio). It is relevant to state that the know-how protection as property does not secure any exclusive rights to the owner by preventing others from attempting to develop the same technical knowledge. However, it secures to the owner the protection of the validity elements of know-how, which are the novelty and the confidentiality or the limited access of the know-how by selected third parties. This also evidences an erga omnes $^{46}$ effect if the peculiarities of know-how are taken into account, as it may be regarded as a true situation of appropriation and dominion by the owner on the intangible. Likewise, patents and trademarks are also peculiar intangibles for enforcement purposes in comparison to property of things under property conceive by the Roman law.

Therefore, the remedies to the know-how owner are secured to infringement of property rights, as stipulated by the Civil Procedural Code and other specific laws. ${ }^{47}$ This includes defensive instruments set by the unfair competition rules provided by the Industrial Property Law to prevent illegal publication or use of the technology that are indispensable for the existence and validity of know-how.

In fact, the stipulation of contractual limitations to those who will have access to the know-how aims exactly to maintain the erga omnes rights in a manner compatible with the peculiarities of know-how.

Notwithstanding the "property value" and the adequate fulfillment of the requirements to be an intangible "legal asset", know-how is not recognized as a property asset due to the legal omission of not framing it as a category of property (under articles 79 to 103 of the Civil Code) nor as moveable. As a result, the legal rights

2010 .

${ }^{44}$ It is further an important requirement the estimate valuable of the know-how (applicable to any moveable) so that it matches with the precise amount of the credit being secured.

${ }^{45}$ Know-how is further used as a guarantee to franchisees that a franchisor holds strong success franchise features in view of the BPTO's backlog of work in prosecuting patents and trademarks.

${ }^{46}$ Erga omnes is a Latin word meaning 'before all" that expresses the binding effects of third parties to the ownership rights secured to the owner of a thing. This means that the owner may prevent any unauthorized third party from using or exploiting the thing required owner's rights.

${ }^{47}$ The legal powers are set out by article 1,228 of the Civil Code and encompass the direct exploitation of the right (ius utendi), the rights to receive the fruits from third parties' exploitation (ius fruendi), and the assignment or sale of the rights to someone else (ius abutendi). Civil Code, article 1,228. "The proprietor has the power to use, exploit and dispose of the thing, and the right to recover it from the power of anyone who wrongfully possesses or hold it." 
secured by property (ius utendi, ius fruendi, ius abutendi and rei vindicatio) - according to article 1,228 of the Civil Code - would not apply to it.

This understanding seems not to be in line with the correct interpretation of the numerus clausus requirement. While this formula prevents private parties solely to create, modify or eliminate Real Rights or the relationship between the owner and the legal asset, it does not deal with the classification of "legal matters" for a property relationship. Accordingly, in principle individuals cannot enlist into article 1,225 of the Civil Code a franchising relationship as a Real Right or property relationship since it is not enlisted as such. However, a thing or "legal asset" ca be a property matter insofar as the asset may be subject to appropriation and exploitation by its owner or by third parties. As an example, patents were not expressly categorized as movables under the previous Industrial Property $\mathrm{Law}^{48}$, but they were understood as adequate industrial property rights and the remedies under the Civil Procedural Code were entirely available to patentees.

One could argue the difficulty of determining and enforcing the property on know-how due to lack of prior registration, but the argument does not seem valid since property of intangibles protected by the Copyright Law is not affected by lack of registration. Therefore, the law cannot prevent protecting know-how due to the absence of specific categorization under the Civil Code and the applicable industrial property rights.

Viewing know-how as a property right does not infringe scholar's legal developments, since the legal relationship between author/inventor and its intellectual creation is similar to those ruling the owner and the thing (res corporales) and the inventor/patentee and its patent. It is important to highlight that the nature of the relationship falls immediately and directly on the intangible matter. It is secured therefore the erga omnes effect intrinsic to the property rights.

Also, as a supporting argument to property protection, Federal Constitution clearly secures the rights to owners of industrial creations, which may encompass unpatented technology and justify the protection of knowhow under the property rights, as follows:

\section{Federal Constitution}

"Article 5. All persons are equal before the law, without any distinction whatsoever, Brazilians and foreigners residing in the country being ensured of inviolability of the right to life, to liberty, to equality, to security and to property, on the following terms:

(...)

XXIX - the law shall ensure the authors of industrial inventions of a temporary privilege for their use, as well as protection of industrial creations, property of trademarks, names of companies and other distinctive signs, viewing the social interest and the technological and economic development of the country;" [free translation, highlight added]

\footnotetext{
${ }^{48}$ Law 5,772 of December 21, 1971. Available at http://www.planalto.gov.br/ccivil_03/leis/L5772.htm. Access on October 10, 2016.
} 
Further to that, the intangibility character of the intellectual works, the use by different persons at the same time (copyrighted literary work, such as a book) or the limitations on a patent use ${ }^{49}$ do not prevent the total efficacy of the erga omnes nor the exercise of the "absolute rights" related to such works. Otherwise, patents, trademarks, industrial design, plant varieties and semiconductors, among others would not be subject to property rights either.

The adequate interpretation of the numerus clausus requirement is provided by ASCENSÃO, as follows: ${ }^{50}$

\begin{abstract}
"The law reserved a monopoly to create Real Rights. Individual persons are prevented from create events of real nature [absolute rights derived from the relationship between the owner and the legal asset] that the law does not provide.

However, only this and this is the sole understanding of typicality. There is no other legal privileged as to the enlisting real rights. What matters is the created regime by law for each asset. If the spokesman finds in a specific asset the essential characteristics of the real right, it will have to quality such right as real, even though the legislator has not expressly made it." [free translation]
\end{abstract}

Therefore, the classification of the assets as property rights was entirely left to the doctrine to decide about and therefore the numerus clausus regime extension should not apply to identifying or not "legal matters". The Brazilian Industrial Property Law does not expressly recognize know-how as property subject matter, but due to its "property value" and similarity to patented inventions, property protection may be extended to know-how.

Under the scholars' studies, know-how receives by the law of the land a tangential protection by means of the combination of unfair competition rules and the Theory of Contract where the know-how owner will enforce its rights on the terms and conditions stipulated in a know-how licensing agreement. In the case of confidential know-how, the protection of the "legal asset" would occur by the execution of a confidentiality agreement, as determined by items XI, XII and XIII of article 195 of the Industrial Property Law.

The rationale behind the aforementioned understanding comes from the prevailing doctrine stating the subjective rights are either protected by Real Rights or by Contractual Rights where the former deals with the intrinsic relationship between the owner and the matter, and the latter refers to transactions between individuals. ${ }^{51}$ Since know-how may be enforceable only against the party who wants to access it and the enforcement does not extend to the collectivity (as in a property right relationship), know-how is understood as an intangible protected by contracts and unfair competition, when secrecy violation takes place.

There is no space for this paper to address in detail the research and digressions related to the relativization of the property rights or the contractual rights or the flexibility of the typicality of real rights. Nonetheless, it is worth stating that the concept differences between property rights and contractual rights can no

\footnotetext{
${ }^{49}$ Article 42 of the Industrial Property Law establishes limitations on the exercise of the property rights, but the limitations do not decrease the granted rights under the patent system.

${ }^{50}$ ASCENSÃO, José de Oliveira, op.cit.,p. 152-153.
} 
longer be applicable. In contractual relationships, the effects do not limit to the contracting parties, as they can also reach third parties and the collectivity. This can be the case of franchising where the franchisor's and franchisee's activities can affect the other franchisees of the franchise chain and the suppliers. If a specific franchisee does not comply with the sanitary rules or does not pay adequately the taxes, the publication of default will mention the name of the franchise chain (not the defaulting franchisee). This will surely affect consumers that will "think twice before going to any franchise unit of that chain" and acquiring the products or hiring the services.

Added to that, the scholar TEPEDINO identifies the multi-property of flats or time-sharing as the possibility of contract mold property rights. According to this type of property, each owner has the right to explore its flat exclusively, but for a determined period since after 3, 4 or 5 months the property will belong to another owner who will have the right to explore it also for a certain period of time and so on. ${ }^{52}$

According to Cristiano Chaves de Farias and Nelson Rosenwald: ${ }^{53}$

"In the end, all observations expressed in the prior topic remit the reader to reevaluate his notions about the property rights. The juridical science in the last 200 years attempted to detach the two groups of patrimonial rights - Real Rights and Contracts - as they were excluding systems and different, to hamper the relativization and consequently the debilitation of the absolute protection of the property rights and the power of the owner on the immovable asset.

However, we perceive clear that property rights are becoming more of a contractual relationship insofar as all Real Rights, without exception; comprise in its structure a Real Right relationship and other contractual relationship. The first market by the dominion situation of the owner on the thing; the second, an intersubjective relationship involving a needed cooperation between the owner of the Real Right and the collectivity." [free translation]

\section{THE RECORDATION PROCEEDINGS AT THE BPTO AND THE KNOW-HOW LICENSING: A PRACTICAL MATTER INFLUENCED BY THE INADEQUATE KNOW- HOW TREATMENT}

Know-how licensing ${ }^{54}$ is classified as a type technology transfer agreement that permits the unpatented technology to be made available and to be exploited in the Brazilian market. Recordation of such know-how transfer agreements is regulated by BPTO's Normative Instruction 16 of March 18, 2013, which replaced Normative Act 135 of April 15, 1997 without relevant changes.

Such rules place the agreement under the scrutiny of the BPTO for recordation proceedings to achieve the following purposes:

\footnotetext{
${ }^{51}$ FARIAS, Cristiano Chaves de F.; ROSENWALD, Nelson, op. cit., p. 1-25.

${ }^{52}$ Idem. P. 12. Also, TEPEDINO, Gustavo. Multipropriedade imobiliária. São Paulo. Saraiva. 1983

${ }^{53}$ Idem, p. 17.

${ }^{54}$ The BPTO uses the terms supply agreement and acquisition of know-how, which reflects its understanding that know-how must not be licensed but only transferred.
} 
i. $\quad$ produce effect before third parties, including the Brazilian Central Bank (BACEN) for remittances overseas and to entitle licensee to proceed in court against the infringement of the licensed patent or trademark, when the agreements provides so;

ii. entitle licensee to proceed with royalty remittances to a foreign licensor and

iii. empower licensee to fiscally deduct the remitted/paid royalties to licensor.

In this regard, it should be said that the legal framework for technology transfer and licensing agreements in Brazil has been marked by government interference due to the fact that imported technology has been an important instrument to foster the local industrialization and development since 1958. Therefore, the Brazilian government regulated the inflow of technology and permitted the sole entry of technologies considered relevant to the Brazilian government and of interest to the economic policy. For such regulation, the government adopted fiscal and foreign exchange control laws and established the need of prior recordation of technology transfer and licensing of industrial property rights.

The control of foreign technology started officially in 1958, when Law 3,578/58 was enacted and established limitations on the amounts of royalties that licensee could fiscally deduct. This law was complemented by Ministerial Ordinance 436 of December 31, 1958 which established categories of deductibility from remuneration remittances based on specific industries. Also, it adopted a deductibility cap for the exploitation of different industrial property rights in diverse activities. For example, patent licensing on oil and gas would permit licensee to obtain a higher deduction up to $5 \%$ of the net revenue, as the technology for the infrastructure was of importance to the import-substitution policy. On the other hand, deductibility of royalties paid for technology (patent or know-how) linked to personal care and for trademarks would be limited to $1 \%$ of the net revenue obtained by licensee derived from the exploitation of the licensed technology/trademark.

The fiscal laws were complemented by Normative Act 15, issued by the BPTO on September 11, 1975. Under this ruling, royalty remittances from all technology transfer and licensing agreements were limited to the fiscal deductibility cap of Ministerial Ordinance 436/58. Further to that, royalty remittances between parentsubsidiary were prohibited.

As to know-how licensing, the BPTO adopted a very restrictive attitude based on the fact such technology was of unpatented nature of limited time-frame. Therefore, it prohibited during the 70's and 80's the recordation of know-how licensing agreements. As a result, the BPTO demanded the title replacement to "Supply of Technology". It further limited the validity period of the agreement to 5 years, with a possibility of renewing it for an additional period of up to 5 years upon justification.

The BPTO also refused the recordation of clauses that obliged licensee to cease the use and return all licensed technology to licensee with contractual termination. Last but not the least, confidentiality clauses were accepted when limited to 5 years maximum, as from the contractual termination.

Despite the revocation of Normative Act 15 and of the new economic policy adopted after 1991, the BPTO maintains some restrictive position towards know-how licensing. The agency no longer requests changes vol.09, nº. 04, Rio de Janeiro, 2016. pp. 2312-2334 2329 
to the title of the agreement, but it still refuses clauses dealing with the return of technology and with the obligation to cease use after termination of the agreement.

An interesting matter in this regard is that the decisions issued by the BPTO were (as still are) based on unwritten rules without further justification. ${ }^{55}$ The justifying reasons are obtained during meetings with the examiners where it is explained that know-how is not an adequate property matter. Therefore, the disposal of the know-how to a third party (licensee) means that the rights are being actually transferred and not licensed. They consider that 5 years would be period under which licensee would have to absorb the technology and use further in the production line without royalty payment, and only exceptionally accept a term of up to 10 years. ${ }^{56}$

\section{CONCLUDING REMARKS}

As discussed in this paper, know-how encompasses all characteristics of a matter entitled to be framed as an industrial property right, being relevant to affirm the "property value" and the appropriation nature that permit the owner to exploit it directly or to obtain revenues through the exploitation by third parties. It also secures to owner the right to recover know-how against unauthorized use by third parties (rei vindicatio) and to obtain compensation for losses and damages.

Therefore, it is notorious that the refusal to accept know-how as a "legal matter" for property rights is an anomaly of the industrial property rights in view of the doctrinal development on the Theory of Property that damages the owner's rights.

In this context, this paper discussed the fallacy that the numerus clausus regime would be applicable to restrict "legal matters" subject to property. It clarified that the main purpose of the numerus clausus as determined by the doctrine is to limit the creation of Real Rights or of new legal institutes capable of determining a relationship between the owner and the thing or "legal matter". Nonetheless, as discussed by this paper, one shall not understand that there is a legal restriction to the interpretation of other relationships as having a property nature if they are clearly based on the fundamental elements of property.

As examined, the adoption of a restrictive understanding of which relationships shall be subject to a property rights regime has extremely damaging effects to transactions involving know-how in Brazil.

\footnotetext{
55 The foreign exchange control laws applicable to licensing of industrial property rights (especially patents and trademarks) include Law 4,131 of September 3, 1962, Law 4,506 of November 30, 1964, Law 8,383 of December 31, 1991, and the regulations of the Brazilian Central Bank (BACEN). Unwritten rules derived from revoked BPTO's regulations are still applicable by the agency when recording technology transfer agreements and licensing agreements. This practice is considered illegal in view of the Principle of Legality that the BPTO and other public agencies are subject to comply. Nevertheless, the BPTO still applies the revoked rules of technology transfer. DIAS, José Carlos Vaz e. "Os Princípios da Legalidade e da Competência e os Limites de Atuação do INPI no Direito de Concorrência.” Revista do IBRAC, São Paulo, v. 5, n. 9., 1988, p. 13-21.

${ }^{56}$ According to $\$ 3^{\circ}$ of article 12 of Law 4, 131 of 1962, the time-frame for fiscal deductibility of the paid remuneration derived from technical assistance and similar agreements will be 5 years as from the introduction of the technology into the local party's production.
} 
More specifically, the BPTO does not accept clauses in know-how licensing agreements that (a) set out the obligation of licensee to cease the technology after termination; (b) determine the return of the technology and documents about it to licensor (or the destruction of such documents) and (c) stipulate confidentiality for a period longer than 5 years as from the date of disclosure.

Such practices, which are not based on express rules, unreasonably limit the property rights constitutionally assured to owners of technologies maintained as know-how, discourage transactions involving such intangible assets and diminish their market value, since owners of know-how are constantly afraid that the conditions mutually agreed upon by the parties may not be enforceable in Brazil.

It is also worth mentioning that the recognition of know-how as a property right would not unbalance the relationship between licensor and licensee. On the contrary, one of the effects of such recognition is precisely the applicability of the principle of the social function of property, which is of tantamount importance to assure that the relationship between owner and its property is exercised in a manner compatible with the interests of a broader range of stakeholders.

This paper proposes further studies on the Theory of Property and on new developments that clarify why institutes and principles of property rights and contract rights should be understood in a more flexible way, so as to duly consider the fundamental elements of property and reflect the complexities of contractual relationships and their effects on transactions involving intangible assets such as know-how.

\section{O TRATAMENTO JURIDICO DO KNOW-HOW NO BRASIL: PECULIARIDADES E CONTROVÉRSIAS DESSA NOVA FORMA INTANGIVEL}

\section{Resumo}

Conhecimentos tecnológicos são um dos ativos mais importantes de uma empresa, na medida em que permite o destacamento competitivo de seus competidores e a qualidade na produção industrial. Dessa forma, conhecimento relevante para o sucesso dos negócios. Uma grande parte desses conhecimentos são expressos na forma de know-how ou 'expertise', não protegido especificamente por patentes ou por qualquer outra forma de direitos da propriedade industrial. Essa falta de uma proteção legal específica releva questionamentos quanto á natureza do know-how e se esse ativo é adequado para exploração e permite ao proprietário assegurar a sua eficácia proprietária contra usos desautorizados. Esse questionamento é relevado pelo fato de o Instituto Nacional da Propriedade Industrial (INPI) não averbar licenciamento de know-how que estipule cláusulas que determinem ao licenciado cessar o uso da tecnologia licenciada e a sua devolução ao licenciamento com o término. Cláusulas de confidencialidade também não são aceitas após o término sob o argumento da absorção tecnológica pelo licenciado.

O objetivo desse artigo é abordar a proteção existente do know-how sob as leis brasileiras e estabelecer a possível natureza jurídica desse ativo, nos moldes da Teoria da Propriedade. Os procedimentos de averbação de contratos de licenciamento serão também abordados como uma tentativa de entender os preconceitos do INPI à proteção do know-how. 
Palavras-chave: Propriedade Privada e Bens Móveis. Direito da Propriedade Industrial. Know-how. Informações Confidenciais. Contrato de Transferência de Tecnologia. Licenciamento de Know-How.

\section{REFERENCE}

ALVES, José Carlos Moreira. Direito Romano. Rio de Janeiro: Forense, 2014, 16. ed., v. 1 and 2.

ASCENSÃO, José de Oliveira. Direito Autoral. Rio de Janeiro: Renovar, 1997, 2. ed.

BARBOSA, Denis Borges. Tratado da Propriedade Intelectual. Rio de Janeiro: Lumens Juris, 2010, Tomo I.

BRAGA, Rodrigo Bernardes. "O Segredo de Negócio no Direito Brasileiro: Trade Secret in the Brazilian Law". Revista Forense, Rio de Janeiro, v. 401, p. 15.

BRANSTETTER, Lee G. et al. "Do stronger Intellectual Property Rights Increase International Technology transfer? Empirical Evidence from U.S. Firm Level Panel Data". The Quarterly Journal of Economics, February 2006, p. 321-349. Available at http://repository.cmu.edu/cgi/viewcontent.cgi?article=1042\&context=sds.

BRASIL. Constitution of the Federal Republic of Brazil of 1988. Available at http://www.planalto.gov.br/ccivil_03/Constituicao/Constituicao.htm.

Law 10,406 of January 10, 2002. Available at http://www.wipo.int/wipolex/en/details.jsp?id=9615.

Law 4,131 ofDecember 30, 1962. Available at http://www.planalto.gov.br/ccivil_03/Leis/L4131.htm.

Law 4,506 of November 30, 1964. Available at http://www.planalto.gov.br/ccivil_03/leis/L4506.htm.

Law 5,771 ofDecember 21, 1972. Available at http://www.planalto.gov.br/ccivil_03/Leis/L5772.htm.

Law 8,078 ofSeptember 11 1990. Available at http://www.planalto.gov.br/ccivil_03/Leis/L8078.htm.

Law 8,383 of December 31, 1991. Available at http://www.planalto.gov.br/ccivil_03/leis/L8383.htm.

Law 8,955 of December 15, 1994. Available at http://www.planalto.gov.br/ccivil_03/leis/18955.htm.

Law 9,279 of May 14, 1996. Available at http://www.planalto.gov.br/ccivil_03/Leis/L9279.htm.

Law 9,610 of February 19, 1998. Available at http://www.planalto.gov.br/ccivil_03/leis/L9610.htm.

Law 3,071 of January 1, 1916. Available at www.planalto.gov.br/ccivil_03/leis/_L3071.htm.

CERQUEIRA, João da Gama. Tratado da Propriedade Industrial. São Paulo: Revista dos Tribunais, 1982, 2. ed., v. I.

COHEN, Jerry; GUTTERMAN, Alan S. Trade Secrets Protection and Exploitation. BNA Books, 1998.

CORREA, Carlos M. "Legal Nature and Contractual Conditions in Know-How Transactions". Georgia Journal of International and Comparative Law, Athens, v. 11, n. 3, 1981, p. 449-494. Available at http://digitalcommons.law.uga.edu/cgi/viewcontent.cgi?article=1958\&context=giicl.

CORREA, José Antonio B. L. Faria "Considerações Sobre o Tratamento do Segredo de Negócio: os efeitos da nova lei de propriedade industrial." Revista da ABPI, Rio de Janeiro / São Paulo, n. 27. March/April, 1997, p. 3038.

DESSEMONTET, François. "Protection of Trade Secrets and Confidential Information.", p. 14-19. Available at https://www.unil.ch/cedidac/files/live/sites/cedidac/files/Articles/Protection\%20Trade\%20Secrets.pdf. 
DIAS, José Carlos Vaz. "Business Transaction of Intellectual Intangibles: The Evidence and Peculiarities of a New Form of Property Rights”. Questio Iuris, Rio de Janeiro, v. 8, n. 3, 2015, p. 2044-2066.

DIAS, José Carlos Vaz; COSTA, João Marcelo Sant'Anna. "Migration of Brazilian intellectual workers in the international market: identification of enticing employees acts and the legal mechanisms to cease the appropriation of technology and unfair competition practices," Revista de Direito Internacional, Rio de Janeiro, v. 13, n. 1,2016, p. 285-307.

DIAS, José Carlos Vaz; PITANGA, Daniel. "Brazil”. In: "Trademarks in 42 jurisdictions worldwide”. Getting the Deal Through, 2010.

"Brazil". In: CAMPBELL, Denis (ed.). "World Intellectual Property Rights and Remedies". Oceana Publications, Inc, New York, 2001.

"Legal Aspects Related to the Joint Ownership of Inventions: The Civil Code and the innovation Law Under Perspective". Revista Semestral de Direito Empresarial, Rio de Janeiro, n. 3. Jul./Dec. 2008, p. 173-213. $20-25$.

"New Brazilian Licensing Rules". In: Managing Intellectual Property Magazine, London, Sep./1993, p.

"New Dress Code for Business Transactions in Brazil: Essentials and Peculiarities of Trademarks in the Spotlight". In: CALBOLI, Irene; WERRA, Jacques (ed.) The Law and Practice of Trademark Transactions: a Global and Local Outlook. Edward Elgar Publishing, 2015.

"Os Princípios da Legalidade e da Competência e os Limites de Atuação do INPI no Direito de Concorrência”. Revista do IBRAC, São Paulo, v. 5, n. 9., 1988, p. 13-21.

DOMINGUES, Douglas Gabriel. "Segredo Industrial, Segredo de Empresa, Trade Secret e Know-how e os Problemas de Segurança das Empresas Contemporâneas.” Revista Forense, Rio de Janeiro, v. 85. n. 308, p. 27-33.

FARIAS, Cristiano Chaves de F.; ROSENWALD, Nelson. Direitos Reais. 3. ed. Rio de Janeiro: Lumen Juris, 2006.

FEKETE, Elizabeth Kaznar. O Regime Jurídico do Segredo de Indústria e Comércio no Direito Brasileiro. Rio de Janeiro: Forense, 2003.

FIGUEIREDO, Paulo. "Problemas do Licenciamento de Tecnologia Não Patenteada". Available at http://www.tjr.jus.br/documents/10136/1186838/prob-licenc-tec-n-patent.pdf.

FISCHER, Georges Charles. “Trade Secrets Protection in Brazil”. Les Nouvelles, Washington, Dec. 1987, p. 69.

GREENBERG, Suzanne F. "The WIPO Model Laws for the Protection of Unpatented Know-How: A Comparative Analysis". Berkeley Journal of International Law, Berkeley, v. 3, 1985, p. 63-65. Available at http://scholarship.law.berkeley.edu/bjil/vol3/iss1/3.

HAYS, Robert C. "Unfair Competition - Another Decade". California Law Review, Berkeley, v. 51, issue 1, 1963, p. 63. Available at http://scholarship.law.berkeley.edu/californialawreview/vol51/iss1/3/.

INSTITUTO NACIONAL DA PROPRIEDADE INDUSTRIAL. Anuário Estatístico de Propriedade Industrial: 2010-2012. Available at http://www.inpi.gov.br/estatisticas/anuario-estatistico-de-propriedadeindustrial-2000-2012.

Boletim Mensal de Propriedade Industrial: Estatísticas Preliminares. Ano I, n. 3, March/2016. Available at http://webcache.googleusercontent.com/search?q=cache:TJlrBej0- 
g0J:www.inpi.gov.br/estatisticas/arquivos/publicacoes/boletim_mar-

2016. $\mathrm{pdf}+\& \mathrm{~cd}=13 \& \mathrm{hl}=\mathrm{en} \& \mathrm{ct}=\mathrm{clnk} \& \mathrm{gl}=\mathrm{br}$.

JORDA, Karl. IP Handbook of Best Practices. Chapter 11.5. Available at http://www.iphandbook.org/handbook/ch11/p05.

LEONARDOS, Gabriel Francisco. Tributação da Transferência de Tecnologia. Rio de Janeiro: Forense, 1997.

NASCIMENTO, João Paulo Capella. "A Natureza Jurídica do Direito sobre os Bens Imateriais". Revista da ABPI, Rio de Janeiro / São Paulo, n. 28, p. 23-32.

PEREIRA, Caio Mário da Silva. Instituições de Direito Civil. Rio de Janeiro: Forense, 2004, 8. ed. v. 4.

PHILLIPS, Jeremy; FIRTH, Alisson. An Introduction to Intellectual Property Rights. Oxford: Oxford University Press, 2005, 4. ed.

ROSE, Leslie. The Brazilian Civil Code in English. Rio de Janeiro: Renovar, 2012, 2. ed.

ROSENN, Keith S. “Brazil's Legal Culture: The Jeito Revisited”. Florida International Law Journal, Gainesville, v. I, fall/1984, p. 5-8.

TEE, David. "The Market for Know-How and the Efficient International Transfer of Technology". Research Paper 608. Graduate School of Business, Stanford University, June 1981, p.1-35.

TEPEDINO, Gustavo. "A Nova Propriedade: o seu Conteúdo Mínimo, entre o Código Civil, a Legislação Ordinária e a Constituição”. Revista Forense, Rio de Janeiro, n. 306, 1989, p. 73-78.

TEPEDINO, Gustavo; BARBOZA, Heloisa Helena; MORAES, Maria Celina Bodin. Código Civil Interpretado, Conforme a Constituição da República. Rio de Janeiro: Renovar, 2014, vol. III. 2. ed.

VENOSA, Silvio de Salvo. Direito Civil: Direitos Reais. São Paulo: Atlas, 2003, 3. ed. v. 5.

WORLD INTELLECTUAL PROPERTY ORGANIZATION. WIPO Model Law for Developing Countries on Invention. 1980, v. II. Available at ftp://ftp.wipo.int/pub/library/ebooks/ModelLaws/84le_vol_2.pdf.

XAVIER, Alberto. Direito Tributário Internacional do Brasil. Rio de Janeiro: Forense, 2007, 6. ed.

Trabalho enviado em 01 de novembro de 2016.

Aceito em 13 de novembro de 2016. 